\title{
Reassessing the ratio of glyoxal to formaldehyde as an indicator of hydrocarbon precursor speciation
}

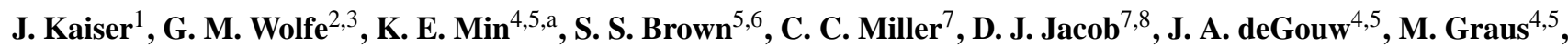 \\ T. F. Hanisco ${ }^{3}$, J. Holloway ${ }^{4,5}$, J. Peischl ${ }^{4,5}$, I. B. Pollack ${ }^{4,5}$, T. B. Ryerson ${ }^{5}$, C. Warneke ${ }^{4,5}$, R. A. Washenfelder ${ }^{4,5}$, and \\ F. N. Keutsch ${ }^{1, \mathrm{~b}}$ \\ ${ }^{1}$ Department of Chemistry, University of Wisconsin-Madison, Madison, Wisconsin, USA \\ ${ }^{2}$ Joint Center for Earth Systems Technology, University of Maryland Baltimore County, Baltimore, Maryland, USA \\ ${ }^{3}$ Atmospheric Chemistry and Dynamics Laboratory, NASA Goddard Space Flight Center, Greenbelt, Maryland, USA \\ ${ }^{4}$ Cooperative Institute for Research in Environmental Sciences, University of Colorado Boulder, Boulder, Colorado, USA \\ ${ }^{5}$ Chemical Sciences Division, NOAA Earth System Research Laboratory, Boulder, Colorado, USA \\ ${ }^{6}$ Department of Chemistry and Biochemistry, University of Colorado, Boulder, Colorado, USA \\ ${ }^{7}$ Department of Earth and Planetary Sciences, Harvard University, Cambridge, Massachusetts, USA \\ ${ }^{8}$ School of Engineering and Applied Sciences, Harvard University, Cambridge, Massachusetts, USA \\ anow at: School of Environmental Science and Engineering, Gwangju Institute for Science and Technology, Gwangju, Korea \\ ${ }^{b}$ now at: School of Engineering and Applied Sciences and Department of Chemistry and Chemical Biology, \\ Harvard University, Cambridge, Massachusetts, USA
}

Correspondence to: J. Kaiser (jen.b.kaiser@gmail.com)

Received: 31 January 2015 - Published in Atmos. Chem. Phys. Discuss.: 04 March 2015

Revised: 12 June 2015 - Accepted: 01 July 2015 - Published: 13 July 2015

\begin{abstract}
The yield of formaldehyde (HCHO) and glyoxal (CHOCHO) from oxidation of volatile organic compounds (VOCs) depends on precursor VOC structure and the concentration of $\mathrm{NO}_{x}\left(\mathrm{NO}_{x}=\mathrm{NO}+\mathrm{NO}_{2}\right)$. Previous work has proposed that the ratio of $\mathrm{CHOCHO}$ to $\mathrm{HCHO}\left(R_{\mathrm{GF}}\right)$ can be used as an indicator of precursor VOC speciation, and absolute concentrations of the $\mathrm{CHOCHO}$ and $\mathrm{HCHO}$ as indicators of $\mathrm{NO}_{x}$. Because this metric is measurable by satellite, it is potentially useful on a global scale; however, absolute values and trends in $R_{\mathrm{GF}}$ have differed between satellite and groundbased observations. To investigate potential causes of previous discrepancies and the usefulness of this ratio, we present measurements of $\mathrm{CHOCHO}$ and $\mathrm{HCHO}$ over the southeastern United States (SE US) from the 2013 SENEX (Southeast Nexus) flight campaign, and compare these measurements with OMI (Ozone Monitoring Instrument) satellite retrievals. High time-resolution flight measurements show that high $R_{\mathrm{GF}}$ is associated with monoterpene emissions, low $R_{\mathrm{GF}}$ is associated with isoprene oxidation, and emissions associated with oil and gas production can lead to small-scale variation in regional $R_{\mathrm{GF}}$. During the summertime in the SE US, $R_{\mathrm{GF}}$
\end{abstract}

is not a reliable diagnostic of anthropogenic VOC emissions, as $\mathrm{HCHO}$ and $\mathrm{CHOCHO}$ production are dominated by isoprene oxidation. Our results show that the new $\mathrm{CHOCHO}$ retrieval algorithm reduces the previous disagreement between satellite and in situ $R_{\mathrm{GF}}$ observations. As the absolute values and trends in $R_{\mathrm{GF}}$ observed during SENEX are largely reproduced by OMI observations, we conclude that satellitebased observations of $R_{\mathrm{GF}}$ can be used alongside knowledge of land use as a global diagnostic of dominant hydrocarbon speciation.

\section{Introduction}

Though volatile organic compounds (VOCs) are present only in trace amounts in the atmosphere, their presence can drive the formation of pollutants such as secondary organic aerosol and ozone. The impact of VOC emissions on tropospheric chemistry depends on the speciation of emitted VOCs and their degradation pathways. As many as $10^{5}$ different species of VOCs are estimated to have been measured in the atmo- 
sphere (Goldstein and Galbally, 2007). While an air mass will usually contain a large variety of VOCs, often a particular species or subset of species (e.g., biogenics) will dominate the photochemistry, giving rise to the production of a range of oxygenated VOCs (OVOCs). Thus, OVOCs can provide downstream constraints on the rates and pathways of VOC oxidation.

Here, we focus on the production of two ubiquitous OVOCs: formaldehyde (HCHO) and glyoxal (CHOCHO). $\mathrm{HCHO}$ is formed from the oxidation of nearly every anthropogenic and biogenic VOC (AVOC/BVOC, respectively). Though photochemical formation is thought to dominate the HCHO global budget (Fortems-Cheiney et al., 2012), direct $\mathrm{HCHO}$ emissions from pyrogenic, anthropogenic, and biogenic activity have also been observed (Guenther et al., 1995; Kesselmeier et al., 1997; Holzinger et al., 1999; Garcia et al., 2006; DiGangi et al., 2011). CHOCHO is formed from the oxidation of a smaller subset of VOCs, particularly alkenes, aromatics, isoprene, and monoterpenes (Fu et al., 2008). Direct emission from biofuel and biomass burning can also be a significant source of CHOCHO (McDonald et al., 2000; Hays et al., 2002; Christian et al., 2003; Greenberg et al., 2006). Because the yields of HCHO and CHOCHO differ between classes of VOC, and because their atmospheric lifetimes are similar, the relative abundance of $\mathrm{CHOCHO}$ and $\mathrm{HCHO}$ has been hypothesized to reflect the speciation of VOCs contributing to total VOC reactivity (Vrekousiss et al., 2010; DiGangi et al., 2012; MacDonald et al., 2012; Li et al., 2014; Miller et al., 2014).

A major motivating factor for examining the ratio of glyoxal to formaldehyde $\left(R_{\mathrm{GF}}\right.$, in units of mole mole $\left.{ }^{-1}\right)$ is the ability to quantify both compounds on a global scale from satellite retrievals. Currently, $\mathrm{HCHO}$ and $\mathrm{CHOCHO}$ are the only two OVOCs with UV-visible absorption features strong enough to enable solar backscatter measurements of vertical column densities. Long-term continuous HCHO columns are available from four satellite-based instruments: GOME (Global Ozone Monitoring Experiment), SCIAMACHY (SCanning Imaging Absorption spectroMeter for Atmospheric CHartographY), OMI (Ozone Monitoring Instrument), and GOME-2. CHOCHO retrievals are available from SCIAMACHY, OMI, and GOME-2. Satellitederived $R_{\mathrm{GF}}$ could be a promising diagnostic tool in determining the speciation of VOC precursors that lead to pollution formation in a given region, especially as retrievals improve in temporal and spatial resolution.

Table 1 summarizes previously published observations and conclusions about $R_{\mathrm{GF}}$. Using GOME-2 satellite retrievals, Vrekoussis et al. (2010) observed $R_{\mathrm{GF}}$ as low as $3 \%$ in anthropogenic regions and between 4 and $6 \%$ over heavily vegetated regions. This was interpreted as an indication that anthropogenic precursors favor $\mathrm{HCHO}$ production relative to $\mathrm{CHOCHO}$, while biogenic precursors favor $\mathrm{CHOCHO}$ production relative to $\mathrm{HCHO}$. Primary emissions of $\mathrm{HCHO}$ were also thought to lower the observed $R_{\mathrm{GF}}$ in anthropogenic regions. In contrast, using ground-based measurements, DiGangi et al. (2012) observed $R_{\mathrm{GF}}$ values typically $<2 \%$ in rural areas, while fresh anthropogenic influence increased $R_{\mathrm{GF}}$ to $4 \%$. These observations yielded a directly contradictory interpretation: AVOCs favor $\mathrm{CHOCHO}$ production, whereas BVOCs favor HCHO production. Furthermore, DiGangi et al. (2012) showed that, given the same VOC speciation, $R_{\mathrm{GF}}$ was invariant despite changes in observed $\mathrm{NO}_{x}$ concentrations. They proposed that this was a result of CHO$\mathrm{CHO}$ and $\mathrm{HCHO}$ formation primarily via the high- $\mathrm{NO}_{x}$ pathway of organic peroxy radical $\left(\mathrm{RO}_{2}\right)$ reactions, which in turn makes the absolute concentration of either OVOC equally dependant on $\mathrm{NO}_{x}$ and therefore leaves $R_{\mathrm{GF}}$ unchanged.

Following these two investigations, high values of $R_{\mathrm{GF}}$ (20-40\%) were observed above an Asian tropical forest (MacDonald et al., 2012), agreeing qualitatively with the conclusion of Vrekoussis et al. (2010) that high $R_{\mathrm{GF}}$ is consistent with biogenic source areas. The reported $R_{\mathrm{GF}}$ values, however, are an order of magnitude greater than satellite observations (Vrekoussis et al., 2010; Miller et al., 2014). Li et al. (2014) report an average $R_{\mathrm{GF}}$ of $6 \%$ at a semi-rural site in southern China. Both observations and model simulations showed that increasing AVOC emissions lead to an increase in $R_{\mathrm{GF}}$. The model simulations indicated $R_{\mathrm{GF}}$ was controlled not only by VOC speciation, but also by $\mathrm{NO}_{x}$ and $\mathrm{OH}$ mixing ratios, as well as physical processes such as $\mathrm{CHOCHO}$ deposition and aerosol uptake (Li et al., 2014). Recently, a new algorithm for the retrieval of CHOCHO from OMI was developed which lessens sensitivity to water vapor abundance and produces on average lower $\mathrm{CHOCHO}$ vertical column densities due to the choice of reference sector (Miller et al., 2014). In contrast to the ranges of $R_{\mathrm{GF}}$ reported by Vrekoussis et al. (2010), the OMI retrieval yields high $R_{\mathrm{GF}}$ in areas associated with monoterpene emissions, intermediate $R_{\mathrm{GF}}$ in areas dominated by anthropogenic emissions, and low $R_{\mathrm{GF}}$ in regions associated with strong isoprene emissions.

The cause of the discrepancies between satellite and ground-based $R_{\mathrm{GF}}$ trends and absolute values are unknown. DiGangi et al. (2012) suggested column-integrated and ground-based measurements in forests may differ due to direct $\mathrm{HCHO}$ emissions, and boundary layer ratios could be systematically lower than free troposphere ratios. Additionally, Miller et al. (2014) highlight interferences from water vapor, reference sector selection, and multi-year averaging as potential causes for the previous errors in satellite retrievals. Despite the different ranges and trends of observed values, all previously published work concludes that $R_{\mathrm{GF}}$ reflects at least in part the speciation of VOCs in a given air mass. If $R_{\mathrm{GF}}$ is to be used as a global tracer of VOC composition, all factors influencing $R_{\mathrm{GF}}$ must be fully elucidated, and satellite retrievals must be validated against field observations.

With flights transecting both anthropogenic and biogenic regions, as well as profiles extending from the boundary layer into the free troposphere, the 2013 SENEX (Southeast Nexus) field campaign provides an unprecedented opportu- 
Table 1. Summary of previously published absolute values and trends of $R_{\mathrm{GF}}$.

\begin{tabular}{|c|c|c|c|c|}
\hline Reference & Method & $\begin{array}{l}R_{\mathrm{GF}} \text { under biogenic } \\
\text { influence }(\%)\end{array}$ & $\begin{array}{l}R_{\mathrm{GF}} \text { under } \\
\text { anthropogenic } \\
\text { influence }(\%)\end{array}$ & $\begin{array}{l}\text { Trend in } R_{\mathrm{GF}} \text { with } \\
\text { anthropogenic } \\
\text { influence }\end{array}$ \\
\hline DiGangi et al. (2012) & $\begin{array}{l}\mathrm{LIF}^{\mathrm{a}} / \mathrm{LIP} \text {; review of previous } \\
\text { ground-based measurements }\end{array}$ & $<2$ & $>2.5$ & Increasing; independent of $\mathrm{NO}_{x}$ \\
\hline Li et al. (2014) & DOAS; model analysis & $0.2-17$ & & $\begin{array}{l}\text { Generally increasing; depends on } \\
\mathrm{NO}_{x}, \mathrm{OH} \text {, and physical processes }\end{array}$ \\
\hline Miller et al. (2014) & Satellite & $\begin{array}{l}<4 \text { (isoprene) } \\
>4 \text { (monoterpenes) }\end{array}$ & $\sim 4$ & Depends on BVOC \\
\hline This work & LIF/ACES $^{\mathrm{d}}$ & $\begin{array}{l}<2.5(\text { isoprene }) \\
>3 \text { (monoterpenes) }\end{array}$ & variable & Depends on BVOC and AVOC \\
\hline
\end{tabular}

${ }^{a}$ Laser-induced fluorescence (HCHO). ${ }^{b}$ Laser-induced phosphorescence (CHOCHO). ${ }^{\mathrm{c}}$ Differential optical absorption spectroscopy. ${ }^{\mathrm{d}}$ Airborne cavity enhanced spectrometer (CHOCHO).

nity to address these uncertainties. Unlike ground-based field campaigns, the flight campaign provides information about the vertical structure of the trace gasses and a direct, real-time comparison of $R_{\mathrm{GF}}$ in urban outflow and in the surrounding rural areas. To our knowledge, this data represents the first high-time-resolution, simultaneous in situ flight-based measurements of $\mathrm{HCHO}$ and $\mathrm{CHOCHO}$. We present absolute mixing ratios of $\mathrm{HCHO}$ and $\mathrm{CHOCHO}$ observed during daytime flights in the southeastern United States (SE US) and discuss the observed relationships of $R_{\mathrm{GF}}$ with observed VOC precursors and anthropogenic influence. Finally, to investigate the applicability of our findings for global studies, we compare flight-based $R_{\mathrm{GF}}$ values with those derived from OMI observations.

\section{Experimental methods}

\subsection{SENEX flight measurements}

During the SENEX project in June and July of 2013, HCHO, $\mathrm{CHOCHO}, \mathrm{NO}_{x}$, and $\mathrm{VOC}$ measurements were acquired simultaneously from the NOAA WP-3D research aircraft during 13 daytime flights. An in-depth description of the SENEX science goals, NOAA WP-3D aircraft, all onboard instrumentation, and each flight plan can be found elsewhere (http://www.esrl.noaa.gov/csd/projects/senex/). A summary of average conditions for each flight is provided in Table S1 in the Supplement.

$\mathrm{HCHO}$ was measured at $1 \mathrm{~Hz}$ by the NASA In Situ Airborne Formaldehyde (ISAF) instrument (Cazorla et al., 2015), which is based on the FIber Laser-Induced Fluorescence (FILIF) technique (Hottle et al., 2009; DiGangi et al., 2011; Kaiser et al., 2014). The reported accuracy of the
$\mathrm{HCHO}$ measurements is $10 \%$. $\mathrm{CHOCHO}$ was measured at $0.2 \mathrm{~Hz}$ by Airborne Cavity Enhanced Spectrometer (ACES) with $6 \%$ accuracy (Washenfelder et al., 2011). The precision of the CHOCHO measurement was a significant fraction of the typical ambient concentration (32 ppt precision, with a typical concentration of $100-150 \mathrm{pptv}$ ), such that precision is a more stringent limitation on data quality than accuracy relative to $\mathrm{HCHO}$, for which the signal was consistently much larger (HCHO precision $25 \mathrm{ppt}$, with concentrations typically $>3 \mathrm{ppb}$ ).

$\mathrm{NO}$ and $\mathrm{NO}_{2}$ were measured by ozone-induced chemiluminescence (CL) and UV photolysis followed by CL, respectively (Ryerson et al., 2000; Pollack et al., 2010). VOCs were measured at $20 \%$ accuracy using proton-transfer reaction mass spectrometry (de Gouw and Warneke, 2007). Unless otherwise specified, all data shown here are filtered to remove in-cloud measurements, measurements below $200 \mathrm{~m}$ or above $1200 \mathrm{~m}$, and data that may be affected by the exhaust of the WP-3D aircraft. $R_{\mathrm{GF}}$ is calculated by averaging the $1 \mathrm{~s} \mathrm{HCHO}$ data to the $5 \mathrm{~s} \mathrm{CHOCHO}$ observations.

\subsection{Satellite retrievals}

The OMI is a nadir viewing UV-visible grating spectrometer, launched onboard the NASA Aura satellite in July 2004 (Levelt et al., 2006). OMI provides daily global coverage at high spatial resolution $(13 \times 24 \mathrm{~km}$ footprint at nadir $)$. We use slant column densities $\left(\Omega_{\mathrm{s}}\right)$ of $\mathrm{HCHO}$ and $\mathrm{CHO}$ CHO from 2006 to 2007 derived from fits to OMI spectra (González Abad et al., 2015; Miller et al., 2014). HCHO and CHOCHO are retrieved between 328.5-365.5 and 435$461 \mathrm{~nm}$, respectively. Slant columns are adjusted to vertical column densities $\left(\Omega_{\mathrm{v}}\right)$ using scattering weights $(S(z))$ archived from the retrieval product, and species concentra- 
tion profiles $(n(z))$ from the GEOS-Chem (Goddard Earth Observing System) chemical transport model (v9-01-03) (Bey et al., 2001; Mao et al., 2013).

$\Omega_{\mathrm{v}}=\Omega_{\mathrm{s}} \frac{\int_{0}^{\infty} n(z) \mathrm{d} z}{\int_{0}^{\infty} S(z) n(z) \mathrm{d} z}$

Here we use daily GEOS-Chem profiles spanning the observation period averaged between 13:00 and 14:00 local time (LT), close to the satellite equatorial crossing time (13:38 LT). The satellite observations are gridded as seasonal averages on a $0.5^{\circ} \times 0.5^{\circ}$ (lat $\times$ long) grid. In this analysis, we use the averaged vertical column densities for June-August of 2007. The overlap between the satellite footprint and output grid is accounted for using an areaweighted tessellation algorithm (Liu et al., 2006). Satellite pixels with cloud fractions larger than 0.2 (derived from the OMI $\mathrm{O}_{2}-\mathrm{O}_{2}$ cloud algorithm (Stammes et al., 2008) and those impacted by the row anomaly (http://www.knmi.nl/ omi/research/product/rowanomaly-background.php) are filtered before gridding.

The sources of errors in satellite measurements are numerous, including uncertainties in temperature-dependent absorption cross sections, the computation of the air mass factor, instrumental errors (e.g., wavelength calibration), potential interferences from other compounds, and low signal to noise. Seasonal averaging helps to reduce these errors. Assuming a $15 \%$ systematic uncertainty and following the formulation thoroughly explained in Vrekoussis et al. (2010), (Sect. 4.3.1), the average error in satellite $R_{\mathrm{GF}}$ over the SE US is 0.005 , which is $18 \%$ of the average $R_{\mathrm{GF}}$ value observed in this region.

\section{Results and discussion}

Figure 1 shows daytime SENEX flight tracks colored by $\mathrm{HCHO}, \mathrm{CHOCHO}$, and $R_{\mathrm{GF}}$, with major emissions sources also indicated. Emissions information was acquired from the Continuous Emissions Monitoring Systems data set for JulySeptember of 2012 (http://ampd.epa.gov/ampd/). In general, $\mathrm{HCHO}$ and $\mathrm{CHOCHO}$ mixing ratios are higher in the areas associated with high BVOC emissions (southern flights). In particular, high $\mathrm{HCHO}$ is observed over the Ozarks "isoprene volcano" (Wiedinmyer et al., 2005). The concentrations of both OVOCs are higher in regions with anthropogenic influence than in the surrounding biogenically dominated areas. Compared to the northern cities of Indianapolis and St. Louis, Birmingham and Atlanta have higher mixing ratios of $\mathrm{HCHO}$ and $\mathrm{CHOCHO}$ in their outflows. The Haynesville shale region has higher mixing ratios of both OVOCs, and $\mathrm{CHOCHO}$ is especially enhanced. While $\mathrm{HCHO}$ and $\mathrm{CHO}-$ $\mathrm{CHO}$ mixing ratios each vary by more than a factor of 4 , the overall variability of $R_{\mathrm{GF}}$ observed during the SENEX flight campaign is low.
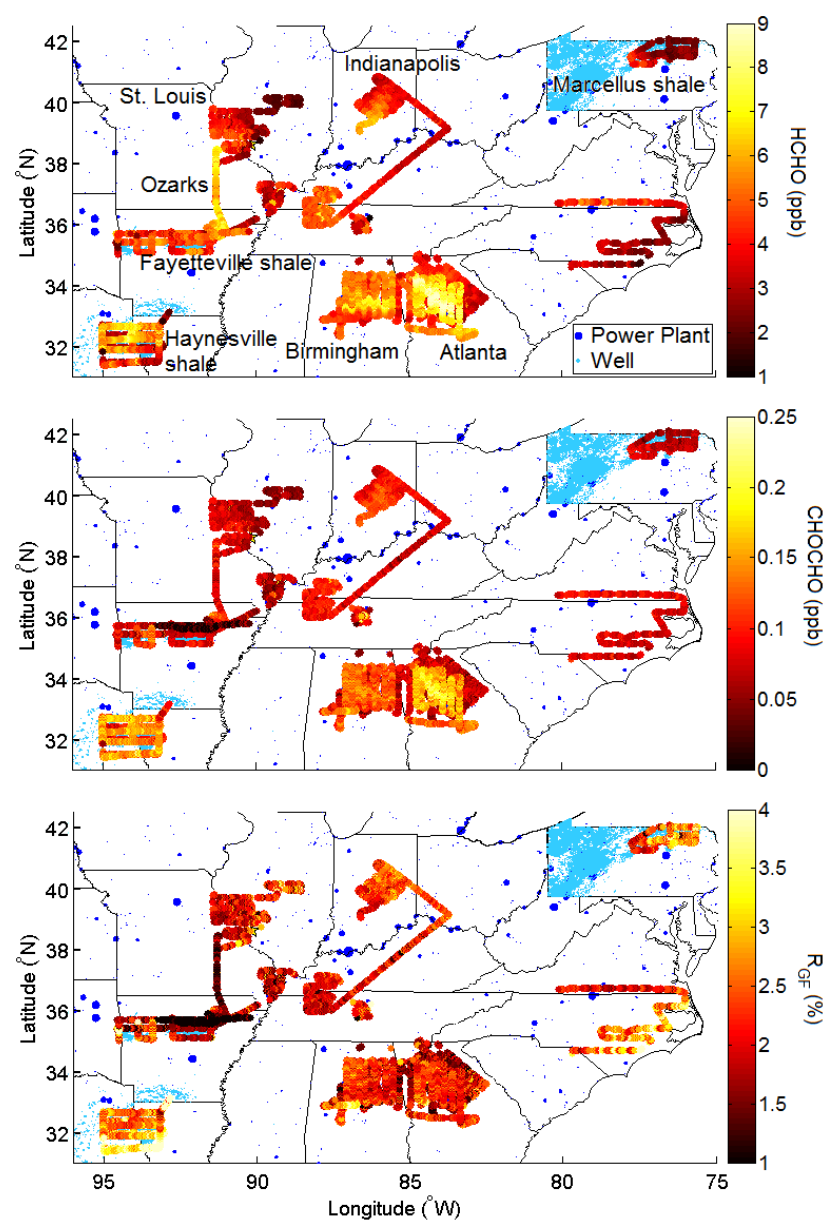

Figure 1. Daytime flight tracks colored by $\mathrm{HCHO}, \mathrm{CHOCHO}$, and $R_{\mathrm{GF}}$. Power plant markers are scaled by $\mathrm{NO}_{x}$ emissions.

Boundary $\mathrm{HCHO}$ and $\mathrm{CHOCHO}$ measurements were also acquired during the Nashville/Middle Tennessee Ozone Study in June/July of 1995. While the SENEX flight tracks more heavily sampled oil and natural gas fields, both studies are mainly representative of the isoprene-rich SE US. The average HCHO mixing ratio is similar (4.2 ppb in 1995, $4.4 \mathrm{ppb}$ in this study), as is the average CHOCHO mixing ratio $(0.07 \mathrm{ppb}$ in $1995,0.10 \mathrm{ppb}$ in this study), leading to similar $R_{\mathrm{GF}}(1.7 \%$ in $1995,2.2 \%$ in this study) (Lee et al., 1998).

Figure 2 shows the same SENEX flight data gridded to the resolution of the OMI satellite retrievals $\left(0.5^{\circ} \times 0.5^{\circ}\right)$. Removing the flights with distinctly high or low $R_{\mathrm{GF}}$ observations $\left(10,25\right.$, and 26 June), the average gridded $R_{\mathrm{GF}}$ is $2.5 \% \pm 0.5 \%$, with a correlation coefficient between $\mathrm{HCHO}$ and CHOCHO of $r^{2}=0.70$. Below, we discuss these regions of notably high and low $R_{\mathrm{GF}}$ as well as the influence of urban emissions on the ratio.

Variability in the time of measurement may have an impact on the comparison of absolute concentrations of both OVOCs and $R_{\mathrm{GF}}$, as measurements were acquired over a range of 


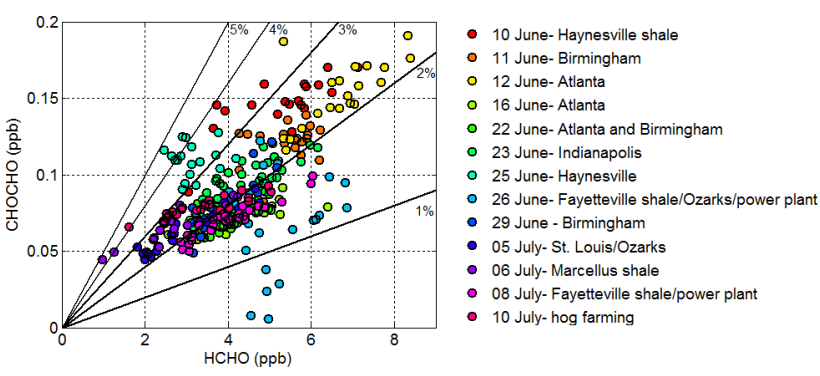

Figure 2. The relationship of $\mathrm{CHOCHO}$ and $\mathrm{HCHO}$ for each flight, gridded to OMI satellite resolution. Flights with extreme values of $R_{\mathrm{GF}}$ include those to the Haynesville shale (10 and 25 June) and the Ozarks (26 June).

mid-day hours $(\sim 10: 00-17: 00$ LT; see Table S1), and both $\mathrm{HCHO}$ and $\mathrm{CHOCHO}$ have strong diurnal cycles. By comparing the observations made within $1 \mathrm{~h}$ on the same day, we aim to minimize any impact that diurnal variation of $R_{\mathrm{GF}}$ would have on this analysis.

\subsection{Regions of high $\boldsymbol{R}_{\mathrm{GF}}$}

During flights on 10 and 25 June, the region responsible for the high observed $R_{\mathrm{GF}}(4-7 \%)$ is in the southeast corner of the flight track, over the Kisatchie National Forest (Fig. 3a, b). The dominant tree species in this region is longleaf pine (http://www.wlf.louisiana.gov). Longleaf pine ( $P i$ nus palustris) is reported to emit monoterpenes but not isoprene (Rasmussen, 1972). The measured emission rate of $\beta$ pinene is the largest, and approximately $30 \%$ greater than the $\alpha$-pinene emission rate. All other monoterpene emission rates are at least an order of magnitude lower (Geron et al., 2000). Indeed, measured monoterpene mixing ratios are elevated over this portion of the flight track (Fig. 3c, d), while isoprene (not shown) is relatively constant over the footprints of both flights. The high-monoterpene/high- $R_{\mathrm{GF}}$ relationship is in agreement with the Miller et al. (2014) satellite observation of high $R_{\mathrm{GF}}$ values above the boreal forests, where the high $\mathrm{CHOCHO}$ yield of monoterpenes is cited as the primary driver of $R_{\mathrm{GF}}$ (Fu et al., 2008). As in the two flights over the Kisatchie Forest, the 26 June flight also highlights a region with high monoterpenes and $R_{\mathrm{GF}}>3 \%$ (arrow in Fig. 4).

Also on the 25 June flight, high $R_{\mathrm{GF}}(>8 \%$ ) is seen on the northeast side of the flight track (circled in Fig. $3 b$ and d). Unlike the high $R_{\mathrm{GF}}$ associated with the monoterpene emissions, these values are not replicated in the same area during the 10 June flight. In this region, $R_{\mathrm{GF}}$ is driven by a decrease in $\mathrm{HCHO}$ mixing ratio while the $\mathrm{CHOCHO}$ mixing ratio is slightly elevated (Fig. 5). Sharp features in meteorological measurements such as potential temperature, an increase in ozone, and a decrease in all other VOC and OVOC mixing ratios suggest an incursion of free tropospheric air. Given the lack of VOC precursors and other oxidation products, and assuming it is not a measurement artifact, the source of CHO-

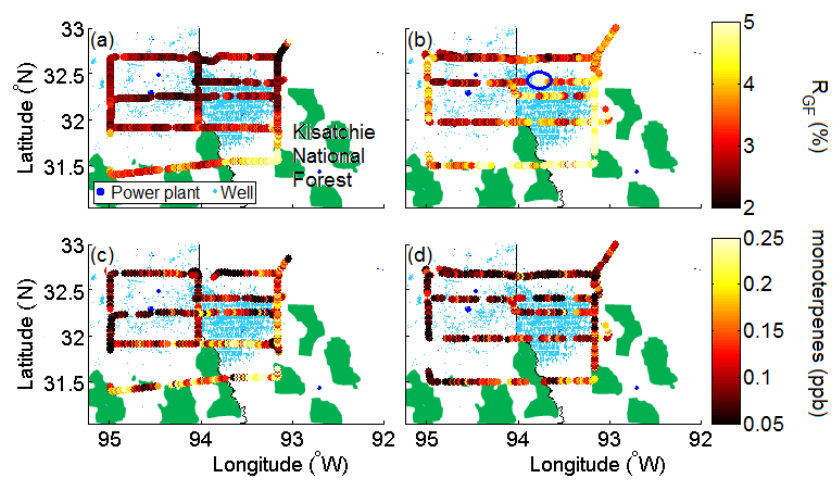

Figure 3. Flight tracks for 10 June $(\mathbf{a}, \mathbf{c})$ and 25 June $(\mathbf{b}, \mathbf{d})$ over the Haynesville shale, colored by $R_{\mathrm{GF}}$ and the measured monoterpene mixing ratio. The southeast corner highlights high $R_{\mathrm{GF}}$ in a region with high monoterpene concentrations. The blue circle indicates the location of high $R_{\mathrm{GF}}$ discussed further in the text. Figure 5 shows meteorological and trace gas measurements acquired at this location. National parks are shown in green, and the Kisatchie National Forest is labeled in (a).
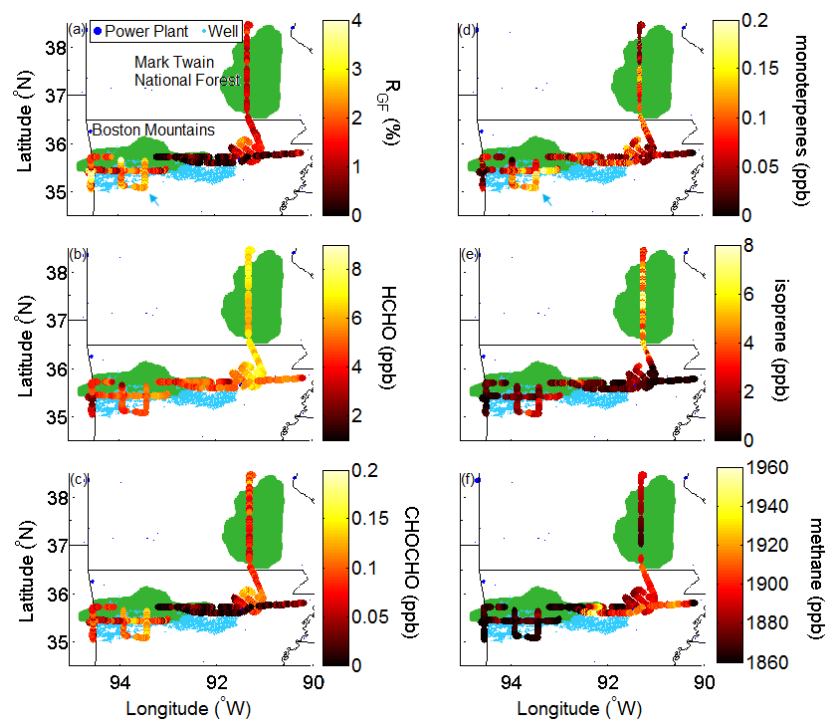

Figure 4. Flight track for 26 June over the Fayetteville shale, the independence power plant, and the Ozarks, colored by the specified trace gas mixing ratio and $R_{\mathrm{GF}}$. The blue arrow highlights the region of elevated monoterpene mixing ratios. National forests are shown in green.

$\mathrm{CHO}$ in the free troposphere is still unknown. The effect of trace gas vertical profile structure on the analysis of $R_{\mathrm{GF}}$ is examined in further detail in Sect. 3.4.

\subsection{Regions of low $R_{\mathrm{GF}}$}

On the 26 June flight, north of the gas production near the eastern side of the flight track, CHOCHO concentrations are low while HCHO mixing ratios are typical of other SENEX observations, driving $R_{\mathrm{GF}}$ to near $0 \%$ (Fig. 4). Concentra- 

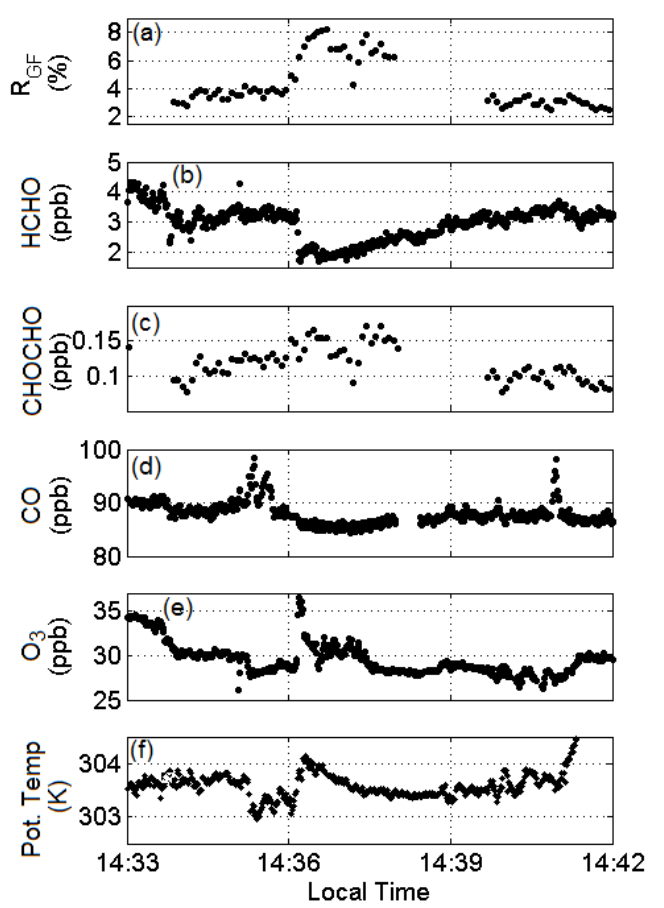

Figure 5. Time series of specified measurements during the rapid increase in $R_{\mathrm{GF}}$ observed south of Shreveport on the 25 June flight (blue circle in Fig. 3). An incursion of free tropospheric air near 14:36 LT drives high $R_{\mathrm{GF}}$.

tions of BVOC and AVOC precursors are also low in this region; however, methane mixing ratios are dramatically elevated. While isoprene is the dominant VOC in terms of calculated $\mathrm{OH}$ reactivity, increased $\mathrm{HCHO}$ relative to $\mathrm{CHOCHO}$ could be a result of oxidation of alkanes, which are associated with oil and natural gas (O\&NG) production (Gilman et al., 2013). Gas flaring could also be a large source of direct HCHO emissions (Pikelnaya et al., 2013).

On the portion of the 26 June flight flown over the Mark Twain National Forest in the Missouri Ozarks (Fig. 4), the average $R_{\mathrm{GF}}$ is $1.1 \pm 0.2 \%$. Here, the average isoprene concentration is high $(7 \pm 2 \mathrm{ppb}), \mathrm{NO}_{x}$ is low $(0.23 \pm 0.02 \mathrm{ppb})$, and AVOC concentrations are low compared to BVOCs (toluene $=0.06 \pm 0.01 \mathrm{ppb}$ ). This suggests relatively pristine regions with strong isoprene emissions can be characterized by low $R_{\mathrm{GF}}$. It is important to note that these measurements were acquired later in the day than most other measurements $(\sim 02: 30 \mathrm{LT}$, Table S1), and approximately $3 \mathrm{~h}$ later than the measurements acquired on the southwest portion of the flight track. We thus cannot rule out diurnal variation as an influence on $R_{\mathrm{GF}}$ in this region.

\subsection{Urban influence on $\boldsymbol{R}_{\mathrm{GF}}$}

Because $R_{\mathrm{GF}}$ may be influenced by AVOC emissions and/or $\mathrm{NO}_{x}$ (Table 1), it has been proposed that $R_{\mathrm{GF}}$ can be used as a diagnostic of the chemistry that leads to $\mathrm{O}_{3}$ formation

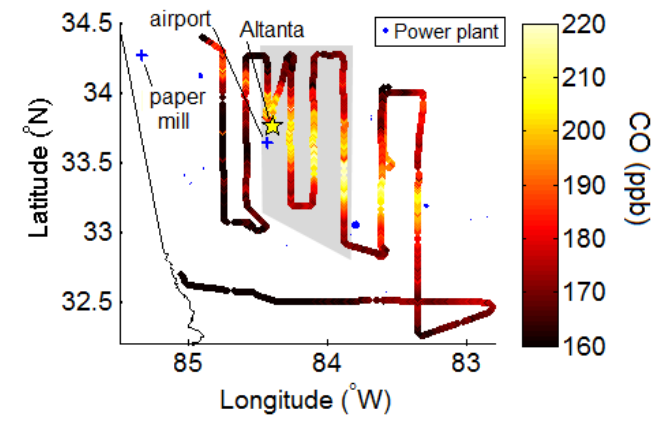

Figure 6. Flight track for 12 June colored by CO, which shows the combined outflow of Atlanta, the airport, and a paper mill on the surrounding background. Measurements acquired in the shaded area are shown in Fig. 7.

(Vrekousiss et al., 2010; DiGangi et al., 2012; Li et al., 2014). Potential explanations for varying $R_{\mathrm{GF}}$ in urban areas include (1) preferential formation of one OVOC from AVOCs, (2) faster oxidation caused by high $\mathrm{OH}$ leading to different relative concentrations of the OVOCs, and (3) differing $\mathrm{NO}_{x}$ dependencies of OVOC yields.

A comparison of in-plume and surrounding background measurements from the 12 June flight through Atlanta can help determine which of these factors may contribute to differences in observed $R_{\mathrm{GF}}$. During this flight, northwesterly winds brought emissions from a nearby paper mill and power plant over the Atlanta area. As it traveled, the plume encountered emissions from the Atlanta international airport and other point and area sources. Figure 6 shows the flight path colored by $\mathrm{CO}$, which demonstrates the boundary between background and polluted air. Figure 7 shows the mixing ratios of isoprene, toluene, $\mathrm{NO}_{x}, \mathrm{HCHO}, \mathrm{CHOCHO}$, and the observed $R_{\mathrm{GF}}$ for the first four transects downwind of Atlanta.

Inside the plume, $\mathrm{NO}_{x}$ is enhanced, AVOCs such as toluene are high, BVOC mixing ratios are low, and concentrations of both OVOCs increased significantly (Fig. 7). However, no clear distinction between in-plume and background measurements can be seen in $R_{\mathrm{GF}}$. This trend in increasing $\mathrm{HCHO}$ and $\mathrm{CHOCHO}$ but consistent $R_{\mathrm{GF}}$ is also seen in several other flight tracks following urban outflow (for further examples see Figs. S1 and S2 in the Supplement highlighting the 5 July flight over St. Louis).

There are two potentially compounding causes of the increase in $\mathrm{HCHO}$ and $\mathrm{CHOCHO}$ concentrations. First, direct emissions of the OVOCs or oxidation of AVOCs in the plume add to the background concentrations of $\mathrm{HCHO}$ and CHOCHO. While the oxidation of the observed AVOCs will increase OVOCs, the contribution of isoprene and its firstgeneration oxidation products methyl vinyl ketone (MVK) and methacrolein (MACR) to $\mathrm{OH}$ reactivity is more than 10 times greater than the contribution from measured AVOCs. Therefore, isoprene is still likely the dominant $\mathrm{HCHO}$ 


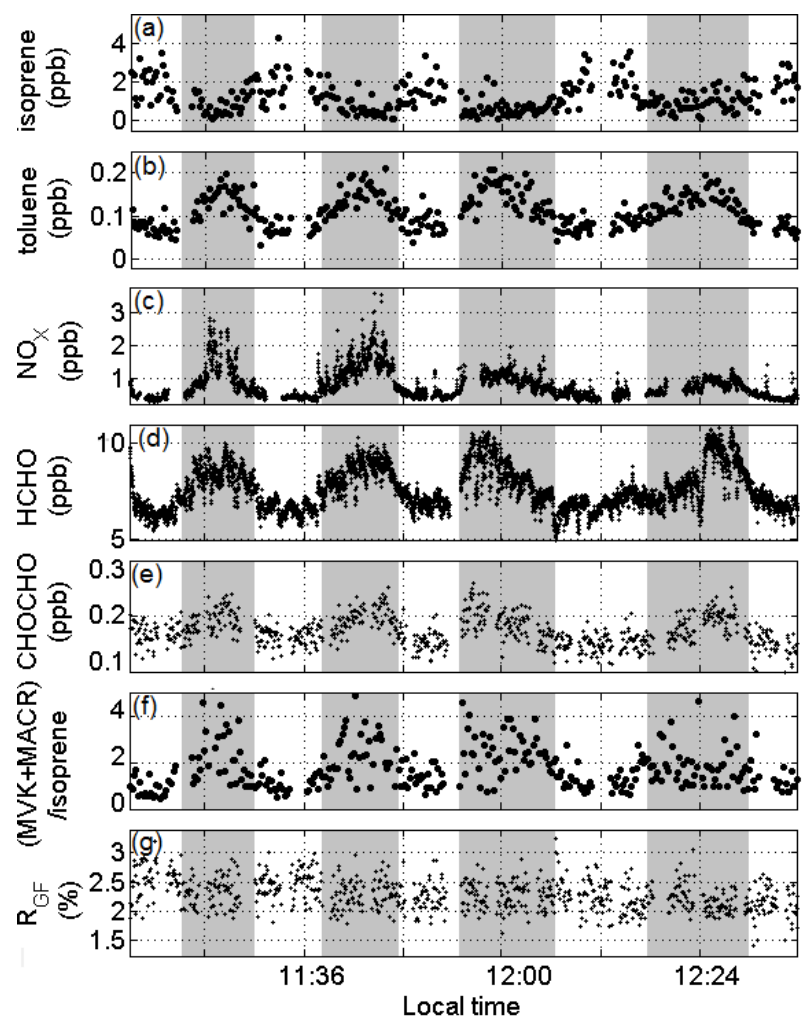

Figure 7. Measurements acquired on the 12 June flight corresponding to the boxed in region in Fig. 6. Shaded regions indicate high anthropogenic influence. While the measurements alter between AVOC/high $\mathrm{NO}_{x}$ and $\mathrm{BVOC} /$ low $\mathrm{NO}_{x}$ regimes, little change is seen in $R_{\mathrm{GF}}$. The maximum values of $\mathrm{NO}_{x}$ and (MVK + MACR) / isoprene fall above the limits shown here.

and $\mathrm{CHOCHO}$ precursor. Second, higher $\mathrm{NO}_{x}$ in the plume leads to more efficient oxidation of VOCs, depleting mixing ratios of primary VOCs such as isoprene and increasing its oxidation products. This is consistent with the classical $\mathrm{NO}_{x}$ dependence of $\mathrm{OH}$ concentrations (Rohrer et al., 2014). The ratio of MVK and MACR to isoprene can be used as an indicator of the extent of photochemical processing (Fig. 7). The higher in-plume ratio of MVK + MACR to isoprene supports the conclusion that oxidation occurs faster in the plume. It is important to note that the low- $\mathrm{NO}_{x}$ oxidation product ISOPOOH (isoprene hydroxy hydroperoxide) can interfere with PTR-MS (proton-transfer reaction mass spectrometry) measurements of MVK + MACR (Rivera-Rios et al., 2014), and potentially also measurements of HCHO. If ISOPOOH creates a positive bias MVK + MACR measurement, the artifact would be larger in the low- $\mathrm{NO}_{x}$ areas, artificially increasing the (MVK + MACR) / isoprene ratio observed outside of the plume. Because (MVK + MACR) / isoprene is higher inside the plume, any interference would not affect the conclusion that oxidation occurs faster in the plume.

The absolute concentrations of $\mathrm{HCHO}$ and $\mathrm{CHOCHO}$ point to more rapid oxidation of isoprene in-plume as well as a potentially small contribution of AVOCs to both overall OVOC budgets, but neither of these characteristics influence $R_{\mathrm{GF}}$. As stated above, a third potential driver of $R_{\mathrm{GF}}$ is a difference in high- and low- $\mathrm{NO}_{x}$ oxidation mechanisms. Again, though the $\mathrm{NO}_{x}$ concentrations observed in-plume are significantly different than the surrounding air such that $\mathrm{RO}_{2}$ spans different fates (reaction with $\mathrm{NO}$ versus reaction with $\mathrm{HO}_{2}$ and isomerization), no characteristic change in $R_{\mathrm{GF}}$ is observed. Therefore, $R_{\mathrm{GF}}$ cannot be used to diagnose AVOC emissions, $\mathrm{RO}_{2}$ fate, or $\mathrm{OH}$ levels in urban areas where isoprene emissions dominate the $\mathrm{HCHO}$ and $\mathrm{CHOCHO}$ budgets.

As discussed in Sect. 3.2, the Ozarks demonstrated especially low $R_{\mathrm{GF}}$. Both the Atlanta background air and the Ozarks are low- $\mathrm{NO}_{x}$ isoprene-dominated regions $(0.5 \mathrm{ppb}$ $\mathrm{NO}_{x}$ near Atlanta, $0.2 \mathrm{ppb} \mathrm{NO}$ in the Ozarks), yet $R_{\mathrm{GF}}$ observations in these areas are significantly different. As previously discussed, urban emissions do not cause significant changes in $R_{\mathrm{GF}}$ if isoprene is the dominant $\mathrm{VOC}$; therefore, some other factor must contribute to the comparably low $R_{\mathrm{GF}}$ over the Ozarks. While the observations of $R_{\mathrm{GF}}$ over the Ozarks were acquired at $\sim 14: 20 \mathrm{LT}$, later observations of $R_{\mathrm{GF}}$ in the plume background are not significantly different than the earlier observations shown in Fig. 7 ( $R_{\mathrm{GF}}$ of $2.2 \pm 0.3 \%$ between 14:00 and 14:30 LT). This suggests that diurnal variation of $R_{\mathrm{GF}}$ is not the driving cause of the difference between Atlanta and Ozark observations.

The most notable difference between the regions is the observed concentrations of isoprene. Isoprene reached over $10 \mathrm{ppb}$ in the Ozarks, while the Atlanta background air reached only $4 \mathrm{ppb}$. A stronger relative contribution of monoterpenes to the $\mathrm{HCHO}$ and $\mathrm{CHOCHO}$ budgets in Atlanta could result in the higher observed $R_{\mathrm{GF}}(\sim 50 \mathrm{ppt}$ monoterepene per pbb isoprene near Atlanta, $\sim 15 \mathrm{ppt}$ monoterepene per ppb isoprene near the Ozarks). Alternatively, the relationship of $\mathrm{HCHO}$ and $\mathrm{CHOCHO}$ with isoprene may be non-linear, with higher isoprene emissions leading to lower $R_{\mathrm{GF}}$. Because low- $\mathrm{NO}_{x}$ isoprene oxidation is not well understood, especially with respect to $\mathrm{OH}$ concentrations (Rohrer et al., 2014), HCHO yields (Palmer et al., 2006; Marais et al., 2012), and CHOCHO yields (Stavrakou et al., 2009), model analysis cannot conclusively determine the cause of decreasing $R_{\mathrm{GF}}$ with increasing isoprene emissions. A model can be useful, however, in determining the anticipated influence of hydrocarbon speciation on $R_{\mathrm{GF}}$, as discussed below.

\subsection{Modeled trends in $\boldsymbol{R}_{\mathrm{GF}}$ with hydrocarbon speciation}

The values of $R_{\mathrm{GF}}$ presented above suggest that (1) monoterpene oxidation leads to higher $R_{\mathrm{GF}}$ than isoprene, (2) AVOCs must have substantially high concentrations to affect $R_{\mathrm{GF}}$ in regions with high isoprene emissions, and (3) depending on the surrounding BVOC emissions, alkanes could decrease 
Table 2. Relative abundance of $\mathrm{HCHO}$ and $\mathrm{CHOCHO}$ from $1 \mathrm{ppb}$ of a given precursor ${ }^{\mathrm{a}}$.

\begin{tabular}{lrrr}
\hline Precursor & CHOCHO & HCHO & Ratio $(\%)^{\mathrm{b}}$ \\
\hline Isoprene & $0.27 \mathrm{ppb}$ & $4.3 \mathrm{ppb}$ & 6.3 \\
$\alpha$-pinene & $0.31 \mathrm{ppb}$ & $3.6 \mathrm{ppb}$ & 8.6 \\
$\beta$-pinene & $0.49 \mathrm{ppb}$ & $3.6 \mathrm{ppb}$ & 14 \\
Ethane & $0.02 \mathrm{ppt}$ & $5.4 \mathrm{ppt}$ & 0.4 \\
Ethene & $586 \mathrm{ppt}$ & $24 \mathrm{ppt}$ & 4.2 \\
Ethyne & $0.91 \mathrm{ppt}$ & $14 \mathrm{ppt}$ & 1500 \\
Propane & $0.02 \mathrm{ppt}$ & $8.8 \mathrm{ppt}$ & 0.2 \\
$n$-butane & $1.5 \mathrm{ppt}$ & $140 \mathrm{ppt}$ & 1.1 \\
Benzene & $23 \mathrm{ppt}$ & $7.6 \mathrm{ppt}$ & 303 \\
Toluene & $103 \mathrm{ppt}$ & $150 \mathrm{ppt}$ & 69 \\
\hline
\end{tabular}

${ }^{a}$ Calculated using a 0-D box model. See text for details.

${ }^{\mathrm{b}}$ Ratio $=$ CHOCHO $/$ HCHO.

the regional $R_{\mathrm{GF}}$. To examine if these results are consistent with our understanding of the oxidation mechanisms of each VOC precursor, a simple 0-D box model analysis was performed using the University of Washington Chemical Box Model (UWCM) (Wolfe and Thornton, 2011), which incorporates the Master Chemical Mechanism v 3.2 (Jenkin et al., 1997; Saunders et al., 2003).

The intent of these model scenarios is not to compare modeled concentrations of $\mathrm{CHOCHO}$ and $\mathrm{HCHO}$ to their observed values, nor to compare modeled and measured $R_{\mathrm{GF}}$, but to investigate the relative values of $R_{\mathrm{GF}}$ predicted by the model for each VOC precursor. Temperature, relative humidity, $\mathrm{O}_{3}$, and $\mathrm{CO}$ are held at their observed campaign averages $(297 \mathrm{~K}, 70 \%, 51$, and $140 \mathrm{ppb}$, respectively). $\mathrm{OH}$ is held at $4 \times 10^{6}$ molec $\mathrm{cm}^{-3}$, and $\mathrm{NO}_{x}$ is constrained to the measured values representative of the plume background on 12 June $\left(\mathrm{NO}=0.06 \mathrm{ppb} ; \mathrm{NO}_{2}=0.41 \mathrm{ppb}\right)$. The solar zenith angle is set to $13.4^{\circ}$, representative of the sun's position over Atlanta at 12:00 LT on 12 June. Pressure is set to a constant 760 Torr, and all species are given an additional sink with a lifetime of $24 \mathrm{~h}$ in lieu of explicitly modeling physical loss processes like deposition and dilution. The only hydrocarbon present in each model scenario is the VOC of interest, held at a constant concentration of $1 \mathrm{ppb}$. Integration time is set to 5 days, at which point the concentrations of both OVOCs are nearly constant. The calculated mixing ratios of CHO$\mathrm{CHO}$ and $\mathrm{HCHO}$ at the end of the model runs are shown in Table 2.

Compared to isoprene, the two monoterpenes investigated here ( $\alpha$ - and $\beta$-pinene) produce more CHOCHO per HCHO. As this effect has been demonstrated in model calculations, satellite observations, and flight-based measurements, we conclude that observations of high values of $R_{\mathrm{GF}}$ are a result of high monoterpene compared to isoprene emissions. The absolute concentrations of both OVOCs produced from the oxidation of AVOCs studied here (benzene, toluene, ethene, ethyne, and the alkanes) are substantially lower compared to
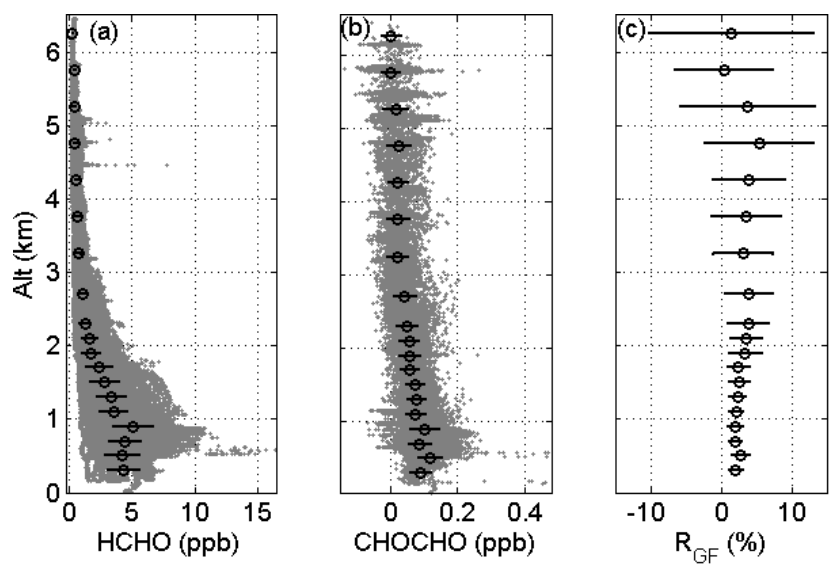

Figure 8. Average vertical profile of (a) $\mathrm{HCHO}$ and (b) $\mathrm{CHO}-$ $\mathrm{CHO}$ measurements acquired during the flights specified in Fig. 1. Gray dots represent all measurements, black circles are averages in a given altitude bin, and error bars are standard deviation within that bin. Bins are $200 \mathrm{~m}$ in height from 200 to $2500 \mathrm{~m}$, and $500 \mathrm{~m}$ thereafter. (c) $R_{\mathrm{GF}}$ calculated from average $\mathrm{HCHO}$ and $\mathrm{CHOCHO}$ profiles. Error bars are calculated from the standard deviations of $\mathrm{HCHO}$ and $\mathrm{CHOCHO}$ observations.

the yield from BVOCs. Because these AVOCs have long lifetimes, the concentration of AVOC would need to be substantially higher than BVOC to dominate the $\mathrm{HCHO}$ or $\mathrm{CHO}-$ CHO budget. This is not likely in most of the SE US. However, AVOCs can dominate chemistry in O\&NG production areas (Katzenstein et al., 2003; Edwards et al., 2014) and may be relatively more important in the winter when BVOC emissions are low or in areas with less vegetation. Alkanes and ethene produce less $\mathrm{CHOCHO}$ per HCHO compared to all BVOCs. In contrast, ethyne, benzene, and toluene produce much more $\mathrm{CHOCHO}$ relative to $\mathrm{HCHO}$. The effect of AVOCs on $R_{\mathrm{GF}}$ is likely dependent on the speciation of emitted AVOCs, the strength of local BVOC emissions, and any direct OVOC emissions (e.g., HCHO from gas flaring). These compounding factors could make measurements of $R_{\mathrm{GF}}$ a convoluted diagnostic for assessing the VOC composition of different air masses.

\subsection{Comparison with satellite retrievals}

While ideally 2013 OMI retrievals would be used in this analysis, the satellite has experienced severe degradation such that quantitative $\mathrm{CHOCHO}$ is not easily determined. Only the 2007 retrievals are available at this time. One of the major conclusions reached using the SENEX in situ measurements is that in the SE US, $R_{\mathrm{GF}}$ is not a diagnostic of anthropogenic emissions, as $\mathrm{HCHO}$ and $\mathrm{CHOCHO}$ production are dominated by isoprene oxidation. Our in situ measurements also show that $R_{\mathrm{GF}}$ is unaffected by $\mathrm{NO}_{x}$ and $\mathrm{OH}$ (Sect. 3.3). Therefore, as long as isoprene is the dominant VOC for HCHO and CHOCHO production in the SE US in both 2007 and 2013, the comparison between 2007 satel- 

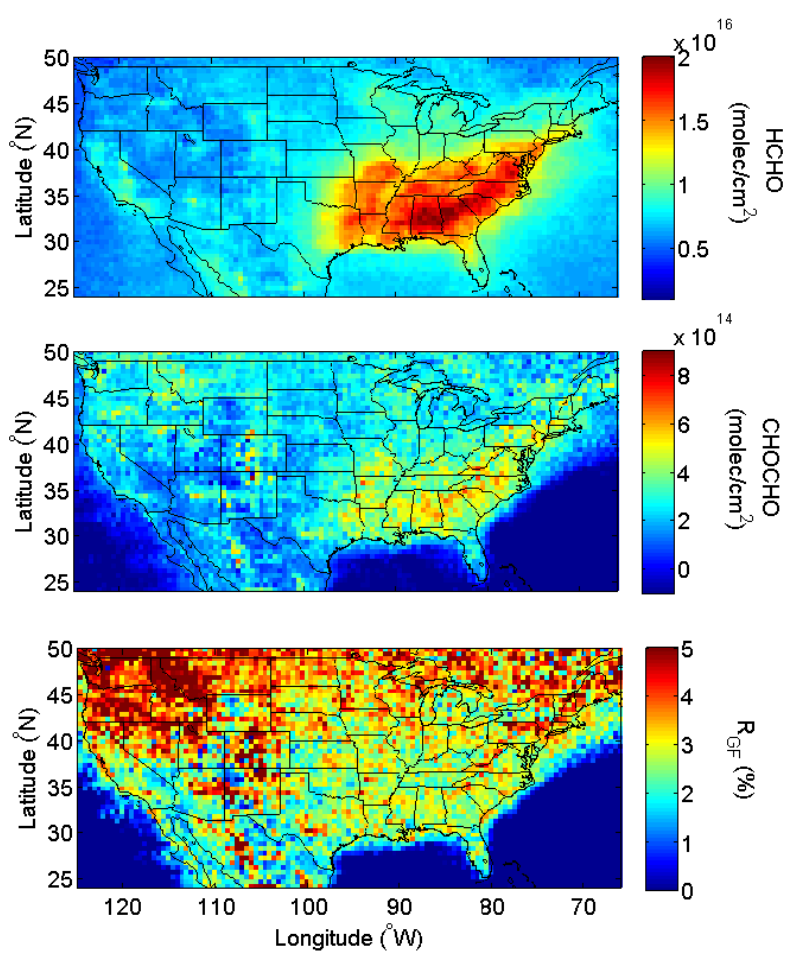

Figure 9. OMI satellite retrievals of $\mathrm{HCHO}$ and $\mathrm{CHOCHO}$ vertical density during June-August of 2007. The ratio to CHOCHO to $\mathrm{HCHO}$ is shown in the bottom panel.

lite and 2013 in situ $R_{\mathrm{GF}}$ remains valid. Both this work and analysis of the previous 1995 Nashville/Middle Tennessee Ozone Study (Lee et al., 1998) find isoprene to be the dominant $\mathrm{HCHO}$ source. Interannual variability of summertime isoprene emissions is estimated to be between 8 and $18 \%$ for the contiguous US during the summers (Tawfik et al., 2012). Therefore, it is likely that isoprene is also the dominant OVOC source in 2007.

When comparing flight-based observations with satellite retrievals, it is important to consider the inherently different information these two measurements provide. Comparisons between column-integrated satellite retrievals and singlealtitude measurements are only valid if the point measurements represent the seasonal mean of the behavior of the vertical column as a whole. To examine any effect of vertical distribution of $\mathrm{HCHO}$ and $\mathrm{CHOCHO}$ on satellite observations of $R_{\mathrm{GF}}$, we investigate the campaign average vertical profiles of both OVOCs and $R_{\mathrm{GF}}$ calculated from those averages (Fig. 8). Both OVOCs show the expected decrease in concentration with altitude; however, the relative difference between boundary layer and free troposphere mixing ratios is greater for $\mathrm{HCHO}$. This gives rise to a small increase in $R_{\mathrm{GF}}$ in the free troposphere. A higher free tropospheric $R_{\mathrm{GF}}$ was also observed in the 1995 Nashville/Middle Tennessee Ozone Study (Lee et al., 1998).

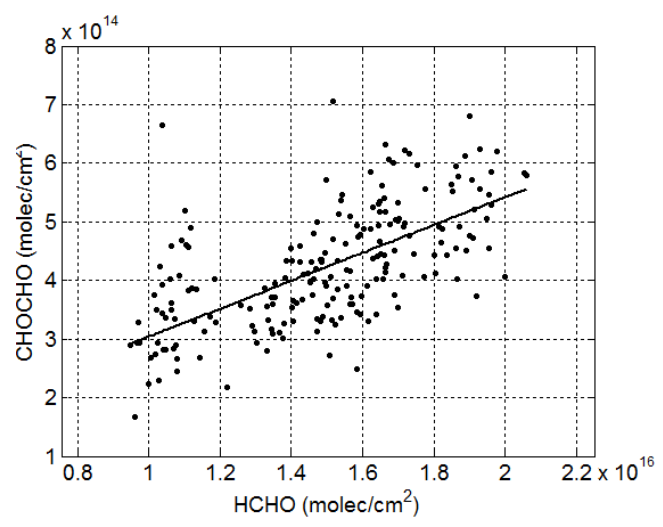

Figure 10. Satellite retrieval of $\mathrm{CHOCHO}$ vs. HCHO corresponding to grid coordinates of SENEX boundary layer measurements. Statistics for the linear fits are shown in Table 4.

While $R_{\mathrm{GF}}$ is typically slightly higher in the free troposphere than the boundary layer, no clear altitude dependence in $R_{\mathrm{GF}}$ is observed within the boundary layer (Fig. 8c, altitudes less than $2 \mathrm{~km}$, and Fig. S4 for individual profiles). In the free troposphere, $\mathrm{CHOCHO}$ measurements are below the detection limit (23 ppt at $3.25 \mathrm{~km}$, detection limit $=32 \mathrm{ppt} 5 \mathrm{~s}^{-1}$ ). The observed variability in $R_{\mathrm{GF}}$ at high altitudes can largely be attributed to noise in the CHO$\mathrm{CHO}$ measurements at such low concentrations. Because the uncertainty in $\mathrm{CHOCHO}$ concentrations from measurement precision is typically greater than that from measurement accuracy, we take measured $\mathrm{CHOCHO}-32 \mathrm{ppt}$ as the lower limit of $\mathrm{CHOCHO}$ as measured by ACES. If measurements are positively biased by as little as $16 \mathrm{ppt}$, which is within this range of uncertainty, corrected data would not demonstrate an increase in $R_{\mathrm{GF}}$ with altitude.

If the difference in $\mathrm{HCHO}$ and $\mathrm{CHOCHO}$ vertical structures is not a measurement artifact, the cause of the increase in $R_{\mathrm{GF}}$ in the free troposphere is unclear. VOC precursors with longer lifetimes that reach the free troposphere could preferentially form $\mathrm{CHOCHO}$; however, all species of measured VOCs exhibit a similar steep decrease in concentration at high altitudes. Alternatively, the lifetimes of $\mathrm{CHOCHO}$ and $\mathrm{HCHO}$ could vary with altitude in such a way that $\mathrm{HCHO}$ concentrations show a more steep vertical dependence. However, this is unlikely as the photolysis and reaction with $\mathrm{OH}$ play nearly identical roles in the relative loss processes of the two OVOCs. Li et al. (2014) inferred different mixing layer heights for the two OVOCs. They calculated that the lifetime of isoprene was shorter than the typical boundary layer mixing time and therefore hypothesized that $\mathrm{HCHO}$ production happened earlier (i.e., at lower altitudes) than $\mathrm{CHOCHO}$ production. In contrast, we see that the boundary layer is typically uniformly mixed with respect to $\mathrm{HCHO}$ and $\mathrm{CHO}$ $\mathrm{CHO}$, potentially signifying the lifetime of the two OVOCs is longer than the boundary layer mixing time. Therefore, the time dependence of $\mathrm{HCHO}$ and $\mathrm{CHOCHO}$ production is un- 
Table 3. Comparison of column-integrated and boundary layer $R_{\mathrm{GF}}$.

\begin{tabular}{|c|c|c|c|c|}
\hline $\begin{array}{l}\text { Profile } \\
\text { number }\end{array}$ & $\begin{array}{r}\text { Boundary } \\
\text { layer } \\
R_{\mathrm{GF}}^{\mathrm{a}}\end{array}$ & $\begin{array}{r}R_{\mathrm{GF}} \text { calculated from } \\
\text { in situ HCHO } \Omega_{\mathrm{V}} \\
\text { and CHOCHO } \Omega_{\mathrm{V}}\end{array}$ & Difference $^{b}$ & $\begin{array}{l}\text { Percentage of altitude } \\
\text { range in } \mathrm{FT}^{\mathrm{c}}\end{array}$ \\
\hline 1 & 2.7 & 3.2 & 0.6 & 68 \\
\hline 2 & 2.2 & 2.6 & 0.4 & 53 \\
\hline 3 & 2.7 & 3.4 & 0.7 & 50 \\
\hline 4 & 2.0 & 2.1 & 0.1 & 50 \\
\hline 5 & 1.7 & 2.1 & 0.4 & 50 \\
\hline 6 & 1.9 & 2.2 & 0.3 & 47 \\
\hline 7 & 2.4 & 2.2 & -0.2 & 42 \\
\hline 8 & 1.9 & 1.9 & 0.0 & 17 \\
\hline 9 & 2.1 & 2.1 & 0.0 & 15 \\
\hline 10 & 2.5 & 1.9 & -0.7 & 15 \\
\hline 11 & 2.6 & 2.4 & -0.2 & 8 \\
\hline 12 & 2.0 & 2.1 & 0.1 & 8 \\
\hline
\end{tabular}

likely to be the underlying cause of the difference in $R_{\mathrm{GF}} \mathrm{ob}-$ served in the free troposphere. Finally, heterogeneous oxidation of aerosols has been proposed as a source of $\mathrm{CHOCHO}$ and other OVOCs in the free troposphere (Volkamer et al., 2015). No specific source of sufficient magnitude has been identified but processes which release glyoxal, such as the ozonolysis of fatty acids (Zhou et al., 2014), would be potential candidates. Any such source would need to produce glyoxal in excess over formaldehyde.

Regardless of the cause of the higher relative $R_{\mathrm{GF}}$ in the free troposphere, because the boundary layer contains the majority of $\mathrm{HCHO}$ and $\mathrm{CHOCHO}$, the $R_{\mathrm{GF}}$ calculated from in situ $\mathrm{HCHO}$ and $\mathrm{CHOCHO}$ vertical column densities is only slightly higher than the average $R_{\mathrm{GF}}$ observed in the boundary layer $\left(2.7 \%\right.$ calculated from $\Omega_{\mathrm{v}}, 2.0 \%$ at $900 \mathrm{~m}$ ). A similar analysis using each local vertical profile measurement rather than the campaign average vertical profiles yields the same conclusions. Table 3 lists the $R_{\mathrm{GF}}$ observed in the boundary layer and the $R_{\mathrm{GF}}$ calculated from in situ $\mathrm{HCHO}$ and $\mathrm{CHOCHO}$ vertical column densities for all profiles extending above $3 \mathrm{~km}$, which were all flown in the AtlantaBirmingham area. A map of profile locations, $\mathrm{HCHO}$ and CHOCHO measurements, and $R_{\mathrm{GF}}$ for each profile can be found in the supporting information (Figs. S3, S4). In general, profiles with a smaller percentage of measurements acquired in the free troposphere do not display a large difference between boundary layer and $R_{\mathrm{GF}}$ calculated from in situ $\mathrm{HCHO}$ and $\mathrm{CHOCHO}$ vertical column densities. Individual profile measurements and campaign-averaged data support the conclusion that $R_{\mathrm{GF}}$ as observed by satellite retrievals should exhibit similar ranges as boundary layer observations, though a positive bias may be observed due to relatively higher $\mathrm{CHOCHO}$ in the free troposphere.

OMI satellite observations from June-August of 2007 over the United States are shown in Fig. 9. HCHO and CHOCHO are elevated over the SE US, where high isoprene emissions are expected to lead to increases in both OVOCs. Compared to the rest of the US, $R_{\mathrm{GF}}$ in this region is low. The northwest
Table 4. Linear fits of CHOCHO vs. HCHO observations ${ }^{\mathrm{a}}$.

\begin{tabular}{lllrr}
\hline Method & Slope & Intercept & $r^{2}$ & Average $R_{\mathrm{GF}}(\%)$ \\
\hline Flight & 0.017 & $0.019 \mathrm{ppb}$ & 0.43 & 2.2 \\
Satellite & 0.024 & $\sim 0.016 \mathrm{ppb}^{\mathrm{b}}$ & 0.38 & 2.8 \\
& & $\left(6.6 \times 10^{13} \mathrm{molec} \mathrm{cm}^{-2}\right)$ & & \\
\hline
\end{tabular}

a All data are gridded to $0.5^{\circ} \times 0.5^{\circ}$ resolution for orthogonal distance regression analysis. For SENEX flight observations, all flights (including Haynesville and Fayetteville areas) are included. ${ }^{\mathrm{b}}$ Ground level mixing ratio was calculated assuming $\mathrm{CHOCHO}$ and $\mathrm{HCHO}$ are contained within a well-mixed $1500 \mathrm{~m}$ boundary layer and an atmospheric-scale height of $7.5 \mathrm{~km}$.

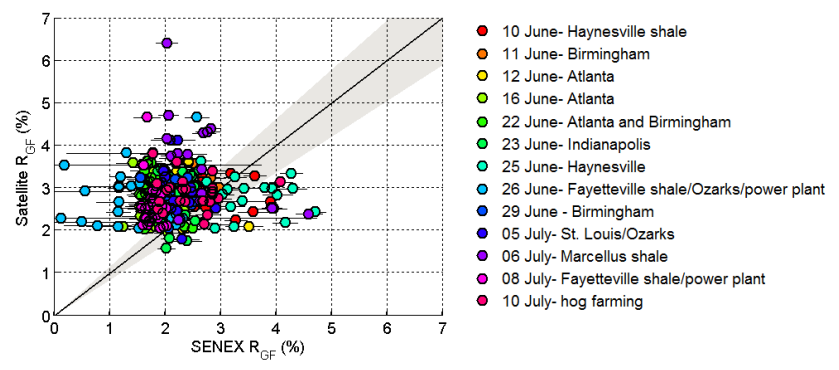

Figure 11. Satellite and SENEX $R_{\mathrm{GF}}$. The line represents a $1-1$ relationship, error bars represent standard deviations of SENEX measurements within the given pixel, and the shaded area represents the accuracy of the SENEX measurements.

region of the US, where monoterpene emissions are high (Sakulyanontvittaya et al., 2008), demonstrates the highest $R_{\mathrm{GF}}$ over the US.

To compare satellite and flight-based observations, flight data were averaged to the $0.5^{\circ} \times 0.5^{\circ} \mathrm{OMI}$ resolution. Summertime satellite retrievals and flight observations of CHO$\mathrm{CHO}$ vs. HCHO show similar correlations, with $r^{2} \sim 0.4$ (Fig. 10, Table 4). The satellite average $R_{\mathrm{GF}}$ is $\sim 0.6$ percentage points higher than flight-based observations gridded to the same resolution. While this cannot be explained by the error and standard deviation of the gridded SENEX data and the uncertainty in the vertical column densities, this percentage is much smaller than the previous discrepancies between satellite and point-based measurements (DiGangi et al., 2012).

Figure 11 shows that while there is no correlation between satellite and flight $R_{\mathrm{GF}}\left(r^{2}=0.003\right)$, the range of observed values are in good agreement $(1.5-4 \%)$. Seasonal averages of $R_{\mathrm{GF}}$ from satellite retrievals are less likely to reflect extreme values and high-emission events compared to flight data; therefore, high correlation is not anticipated at this timescale. Similarly, the correlations between satellite and ground $\mathrm{HCHO}\left(r^{2}=0.15\right)$ and $\mathrm{CHOCHO}$ $\left(r^{2}=0.044\right)$ are low. Satellite and flight HCHO observations show stronger correlation than $\mathrm{CHOCHO}$ observations likely because $\mathrm{CHOCHO}$ aircraft measurements and satellite retrievals have higher relative uncertainties than $\mathrm{HCHO}$ retrievals (Miller et al., 2014; González Abad et al., 2015), and in situ CHOCHO measurements are close to the detection limit. The high and low values of $R_{\mathrm{GF}}$ observed during the 
SENEX field campaign ( 25 and 26 June flights) are not reproduced in the satellite observations. A comparison of average BVOC emissions and O\&NG production activity during the summer of 2007 and June 2013 would be needed to demonstrate that satellite $R_{\mathrm{GF}}$ would be expected to show similar deviations from its average value. Furthermore, small-scale variation in satellite $R_{\mathrm{GF}}$ is mostly associated with noise, such that retrievals shown cannot distinguish the local influences (i.e., the Kisatchie National forest).

Besides the new $\mathrm{CHOCHO}$ retrieval method, one key distinction between this comparison and comparisons in previous studies (i.e., DiGangi et al., 2012) is the use of satellite retrievals for only the summer observational period rather the annual averages. Ground- and flight-based measurements are typically performed in the summer, when BVOC emissions are high. Therefore, point-based measurements may be biased to display the influence of BVOC emissions on $R_{\mathrm{GF}}$.

\section{Conclusions: Can $\boldsymbol{R}_{\mathrm{GF}}$ be used as a global indicator of VOC speciation?}

Overall, the flight-based measurements presented here show that $R_{\mathrm{GF}}$ is indicative of VOC speciation in select situations. High $R_{\mathrm{GF}}(>3 \%)$ is consistently observed in areas with high monoterpene emissions, and low $R_{\mathrm{GF}}(<2.5 \%)$ is associated with strong isoprene emissions. No consistent influence of AVOC or $\mathrm{NO}_{x}$ emissions on the background $R_{\mathrm{GF}}$ was observed, likely because biogenic VOC emission strength determines $R_{\mathrm{GF}}$ in the SE US. The previously observed quick and short (2-5 min) increase in $R_{\mathrm{GF}}$ in DiGangi et al. (2012) may have been a result of extremely fresh emissions (e.g., diesel trucks emit at a rate of $\mathrm{CHO}$ $\mathrm{CHO} / \mathrm{HCHO}=9.4 \%$; Schauer et al., 1999), and not indicative of larger-scale changes in dominant VOC speciation. Emissions associated with oil and gas production areas can cause $R_{\mathrm{GF}}$ to deviate from the values observed over their background levels. However, the absolute value of $R_{\mathrm{GF}}$ in such regions is likely dependent on background BVOC emissions, speciation of AVOCs, and any direct OVOC emissions.

Compared to previous literature, absolute values of flightbased $R_{\mathrm{GF}}$ are in better agreement with satellite observations using the new $\mathrm{CHOCHO}$ retrieval algorithms. While time resolution plays a large role in direct comparisons of pointbased measurements and satellite retrievals, the trend of high $R_{\mathrm{GF}}$ over areas with monoterpenes and low $R_{\mathrm{GF}}$ over areas with isoprene is broadly in agreement for the two platforms. With these trends validated by ground measurements, $R_{\mathrm{GF}}$ based on satellite retrievals may be useful as a diagnostic of BVOC emissions. As these retrievals become available at higher time and spatial resolutions, $R_{\mathrm{GF}}$ can be used to help identify the speciation of VOCs leading to secondary pollutant formation on a regional scale.

\section{The Supplement related to this article is available online at doi:10.5194/acp-15-7571-2015-supplement.}

Acknowledgements. The authors would like to acknowledge the contribution from all members of the SENEX flight and science teams. Funding was provided by US EPA Science to Achieve Results (STAR) program grant 83540601. This research has not been subjected to any EPA review and therefore does not necessarily reflect the views of the agency, and no official endorsement should be inferred. J. Kaiser acknowledges support from NASA Headquarters under the NASA Earth and Space Science Fellowship Program - grant NNX14AK97H. This work was also supported as part of the NASA Aura Science Team.

Edited by: R. McLaren

\section{References}

Bey, I., Jacob, D. J., Yantosca, R. M., Logan, J. A., Field, B. D., Fiore, A. M., Li, Q. B., Liu, H. G. Y., Mickley, L. J., and Schultz, M. G.: Global modeling of tropospheric chemistry with assimilated meteorology: Model description and evaluation, J. Geophys. Res.-Atmos., 106, 23073-23095, doi:10.1029/2001jd000807, 2001.

Cazorla, M., Wolfe, G. M., Bailey, S. A., Swanson, A. K., Arkinson, H. L., and Hanisco, T. F.: A new airborne laser-induced fluorescence instrument for in situ detection of formaldehyde throughout the troposphere and lower stratosphere, Atmos. Meas. Tech., 8, 541-552, doi:10.5194/amt-8-541-2015, 2015.

Christian, T. J., Kleiss, B., Yokelson, R. J., Holzinger, R., Crutzen, P. J., Hao, W. M., Saharjo, B. H., and Ward, D. E.: Comprehensive laboratory measurements of biomass-burning emissions: 1 . Emissions from Indonesian, African, and other fuels, J. Geophys. Res., 108, 4719, doi:10.1029/2003jd003704, 2003.

de Gouw, J. and Warneke, C.: Measurements of volatile organic compounds in the earths atmosphere using proton-transferreaction mass spectrometry, Mass Spectrom. Rev., 26, 223-257, doi:10.1002/mas.20119, 2007.

DiGangi, J. P., Boyle, E. S., Karl, T., Harley, P., Turnipseed, A., Kim, S., Cantrell, C., Maudlin III, R. L., Zheng, W., Flocke, F., Hall, S. R., Ullmann, K., Nakashima, Y., Paul, J. B., Wolfe, G. M., Desai, A. R., Kajii, Y., Guenther, A., and Keutsch, F. N.: First direct measurements of formaldehyde flux via eddy covariance: implications for missing in-canopy formaldehyde sources, Atmos. Chem. Phys., 11, 10565-10578, doi:10.5194/acp-1110565-2011, 2011.

DiGangi, J. P., Henry, S. B., Kammrath, A., Boyle, E. S., Kaser, L., Schnitzhofer, R., Graus, M., Turnipseed, A., Park, J-H., Weber, R. J., Hornbrook, R. S., Cantrell, C. A., Maudlin III, R. L., Kim, S., Nakashima, Y., Wolfe, G. M., Kajii, Y., Apel, E.C., Goldstein, A. H., Guenther, A., Karl, T., Hansel, A., and Keutsch, F. N.: Observations of glyoxal and formaldehyde as metrics for the anthropogenic impact on rural photochemistry, Atmos. Chem. Phys., 12, 9529-9543, doi:10.5194/acp-12-9529-2012, 2012.

Edwards, P. M., Brown, S. S., Roberts, J. M., Ahmadov, R., Banta, R. M., deGouw, J. A., Dube, W. P., Field, R. A., Flynn, J. H., 
Gilman, J. B., Graus, M., Helmig, D., Koss, A., Langford, A. O., Lefer, B. L., Lerner, B. M., Li, R., Li, S.-M., McKeen, S. A., Murphy, S. M., Parrish, D. D., Senff, C. J., Soltis, J., Stutz, J., Sweeney, C., Thompson, C. R., Trainer, M. K., Tsai, C., Veres, P. R., Washenfelder, R. A., Warneke, C., Wild, R. J., Young, C. J., Yuan, B., and Zamora, R.: High winter ozone pollution from carbonyl photolysis in an oil and gas basin, Nature, 514, 351354, 10.1038/nature13767, 2014.

Fortems-Cheiney, A., Chevallier, F., Pison, I., Bousquet, P., Saunois, M., Szopa, S., Cressot, C., Kurosu, T. P., Chance, K., and Fried, A.: The formaldehyde budget as seen by a global-scale multiconstraint and multi-species inversion system, Atmos. Chem. Phys., 12, 6699-6721, doi:10.5194/acp-12-6699-2012, 2012.

Fu, T.-M., Jacob, D. J., Wittrock, F., Burrows, J. P., Vrekoussis, M., and Henze, D. K.: Global budgets of atmospheric glyoxal and methylglyoxal, and implications for formation of secondary organic aerosols, J. Geophys. Res.-Atmos., 113, D15303, doi:10.1029/2007jd009505, 2008.

Garcia, A. R., Volkamer, R., Molina, L. T., Molina, M. J., Samuelson, J., Mellqvist, J., Galle, B., Herndon, S. C., and Kolb, C. E.: Separation of emitted and photochemical formaldehyde in Mexico City using a statistical analysis and a new pair of gas-phase tracers, Atmos. Chem. Phys., 6, 4545-4557, doi:10.5194/acp-64545-2006, 2006.

Geron, C., Guenther, A., Sharkey, T., and Arnts, R. R.: Temporal variability in basal isoprene emission factor, Tree Physiol., 20, 799-805, doi:10.1093/treephys/20.12.799, 2000.

Gilman, J. B., Lerner, B. M., Kuster, W. C., and de Gouw, J. A.: Source Signature of Volatile Organic Compounds from Oil and Natural Gas Operations in Northeastern Colorado, Environ. Sci. Technol., 47, 1297-1305, doi:10.1021/es304119a, 2013.

Goldstein, A. H. and Galbally, I. E.: Known and unexplored organic constituents in the earth's atmosphere, Environ. Sci. Technol., 41, 1514-1521, doi:10.1021/es072476p, 2007.

González Abad, G., Liu, X., Chance, K., Wang, H., Kurosu, T. P., and Suleiman, R.: Updated Smithsonian Astrophysical Observatory Ozone Monitoring Instrument (SAO OMI) formaldehyde retrieval, Atmos. Meas. Tech., 8, 19-32, doi:10.5194/amt-8-192015, 2015.

Greenberg, J. P., Friedli, H., Guenther, A. B., Hanson, D., Harley, P., and Karl, T.: Volatile organic emissions from the distillation and pyrolysis of vegetation, Atmos. Chem. Phys., 6, 81-91, doi:10.5194/acp-6-81-2006, 2006.

Guenther, A., Hewitt, C. N., Erickson, D., Fall, R., Geron, C., Graedel, T., Harley, P., Klinger, L., Lerdau, M., McKay, W. A., Pierce, T., Scholes, B., Steinbrecher, R., Tallamraju, R., Taylor, J., and Zimmerman, P.: A global model of natural volatile compound emissions, J. Geophys. Res.-Atmos., 100, 8873-8892, doi:10.1029/94jd02950, 1995.

Hays, M. D., Geron, C. D., Linna, K. J., Smith, N. D., and Schauer, J. J.: Speciation of gas-phase and fine particle emissions from burning of foliar fuels, Environ. Sci. Technol., 36, 2281-2295, doi:10.1021/es0111683, 2002.

Holzinger, R., Warneke, C., Hansel, A., Jordan, A., Lindinger, W., Scharffe, D. H., Schade, G., and Crutzen, P. J.: Biomass burning as a source of formaldehyde, acetaldehyde, methanol, acetone, acetonitrile, and hydrogen cyanide, Geophys. Res. Lett., 26, 1161-1164, doi:10.1029/1999g1900156, 1999.
Hottle, J., Huisman, A., Digangi, J., Kammrath, A., Galloway, M., Coens, K., and Keutsch, F.: A Laser Induced Fluorescence-Based Instrument for In-Situ Measurements of Atmospheric Formaldehyde, Environ. Sci. Technol., 43, 790-795, doi:10.1021/es801621f, 2009.

Jenkin, M., Saunders, S., and Pilling, M.: The tropospheric degradation of volatile organic compounds: A protocol for mechanism development, Atmos. Environ., 31, 81-104, doi:10.1016/S13522310(96)00105-7, 1997.

Kaiser, J., Li, X., Tillmann, R., Acir, I., Holland, F., Rohrer, F., Wegener, R., and Keutsch, F. N.: Intercomparison of Hantzsch and fiber-laser-induced-fluorescence formaldehyde measurements, Atmos. Meas. Tech., 7, 1571-1580, doi:10.5194/amt-7-15712014, 2014.

Katzenstein, A. S., Doezema, L. A., Simpson, I. J., Balke, D. R., and Rowland, F. S.: Extensive regional atmospheric hydrocarbon pollution in the southwestern United States, P. Natl. Acad. Sci. USA, 100, 11975-11979, doi:10.1073/pnas.1635258100, 2003.

Kesselmeier, J., Bode, K., Hofmann, U., Muller, H., Schafer, L., Wolf, A., Ciccioli, P., Brancaleoni, E., Cecinato, A., Frattoni, M., Foster, P., Ferrari, C., Jacob, V., Fugit, J. L., Dutaur, L., Simon, V., and Torres, L.: Emission of short chained organic acids, aldehydes and monoterpenes from Quercus ilex L. and Pinus pinea L. in relation to physiological activities, carbon budget and emission algorithms, Atmos. Environ., 31, 119-133, doi:10.1016/s1352-2310(97)00079-4, 1997.

Lee, Y. N., Zhou, X., Kleinman, L. I., Nunnermacker, L. J., Springston, S. R., Daum, P. H., Newman, L., Keigley, W. G., Holdren, M. W., Spicer, C. W., Young, V., Fu, B., Parrish, D. D., Holloway, J., Williams, J., Roberts, J. M., Ryerson, T. B., and Fehsenfeld, F. C.: Atmospheric chemistry and distribution of formaldehyde and several multioxygenated carbonyl compounds during the 1995 Nashville Middle Tennessee Ozone Study, J. Geophys. Res., 103, 22449-22462, doi:10.1029/98JD01251, 1998.

Levelt, P. F., Van den Oord, G. H. J., Dobber, M. R., Malkki, A., Visser, H., de Vries, J., Stammes, P., Lundell, J. O. V., and Saari, H.: The Ozone Monitoring Instrument, IEEE T. Geosci. Remote Sens., 44, 1093-1101, doi:10.1109/tgrs.2006.872333, 2006.

Li, X., Rohrer, F., Brauers, T., Hofzumahaus, A., Lu, K., Shao, M., Zhang, Y. H., and Wahner, A.: Modeling of HCHO and CHO$\mathrm{CHO}$ at a semi-rural site in southern China during the PRIDEPRD2006 campaign, Atmos. Chem. Phys., 14, 12291-12305, doi:10.5194/acp-14-12291-2014, 2014.

Liu, X., Chance, K., Sioris, C. E., Kurosu, T. P., Spurr, R. J. D., Martin, R. V., Fu, T. M., Logan, J. A., Jacob, D. J., Palmer, P. I., Newchurch, M. J., Megretskaia, I. A., and Chatfield, R. B.: First directly retrieved global distribution of tropospheric column ozone from GOME: Comparison with the GEOS-CHEM model, J. Geophys. Res.-Atmos., 111, D02308, doi:10.1029/2005jd006564, 2006.

MacDonald, S. M., Oetjen, H., Mahajan, A. S., Whalley, L. K., Edwards, P. M., Heard, D. E., Jones, C. E., and Plane, J. M C.: DOAS measurements of formaldehyde and glyoxal above a south-east Asian tropical rainforest, Atmos. Chem. Phys., 12, 5949-5962, doi:10.5194/acp-12-5949-2012, 2012.

Mao, J., Paulot, F., Jacob, D. J., Cohen, R. C., Crounse, J. D., Wennberg, P. O., Keller, C. A., Hudman, R. C., Barkley, M. P., and Horowitz, L. W.: Ozone and organic nitrates over the east- 
ern United States: Sensitivity to isoprene chemistry, J. Geophys. Res.-Atmos., 118, 11256-11268, doi:10.1002/jgrd.50817, 2013.

Marais, E. A., Jacob, D. J., Kurosu, T. P., Chance, K., Murphy, J. G., Reeves, C., Mills, G., Casadio, S., Millet, D. B., Barkley, M. P., Paulot, F., and Mao, J.: Isoprene emissions in Africa inferred from OMI observations of formaldehyde columns, Atmos. Chem. Phys., 12, 6219-6235, doi:10.5194/acp-12-62192012, 2012.

McDonald, J. D., Zielinska, B., Fujita, E. M., Sagebiel, J. C., Chow, J. C., and Watson, J. G.: Fine particle and gaseous emission rates from residential wood combustion, Environ. Sci. Technol., 34, 2080-2091, doi:10.1021/es9909632, 2000.

Miller, C., Gonzalez Abad, G., Wang, H., Liu, X., Kurosu, T., Jacob, D. J., and Chance, K.: Glyoxal retrieval from the Ozone Monitoring Instrument, Atmos. Meas. Tech., 7, 3891-3907, doi:10.5194/amt-7-3891-2014, 2014.

Palmer, P. I., Abbot, D. S., Fu, T.-M., Jacob, D. J., Chance, K., Kurosu, T. P., Guenther, A., Wiedinmyer, C., Stanton, J. C., Pilling, M. J., Pressley, S. N., Lamb, B., and Sumner, A. L.: Quantifying the seasonal and interannual variability of North American isoprene emissions using satellite observations of the formaldehyde column, J. Geophys. Res.-Atmos., 111, D12315, doi:10.1029/2005jd006689, 2006.

Pikelnaya, O., Flynn, J. H., Tsai, C., and Stutz, J.: Imaging DOAS detection of primary formaldehyde and sulfur dioxide emissions from petrochemical flares, J. Geophys. Res.-Atmos., 118, 87168728, doi:10.1002/jgrd.50643, 2013.

Pollack, I. B., Lerner, B. M., and Ryerson, T. B.: Evaluation of ultraviolet light-emitting diodes for detection of atmospheric $\mathrm{NO}_{2}$ by photolysis - chemiluminescence, J. Atmos. Chem., 65, 111-125, doi:10.1007/s10874-011-9184-3, 2010.

Rasmussen, R. A.: What do the hydrocarbons from trees contribute to air pollution?, J. Air Pollut. Contr. Assoc., 22, 537-543, 1972.

Rivera-Rios, J. C., Nguyen, T. B., Crounse, J. D., Jud, W., St. Clair, J. M., Mikoviny, T., Gilman, J. B., Lerner, B. M., Kaiser, J. B., de Gouw, J., Wisthaler, A., Hansel, A., Wennberg, P. O., Seinfeld, J. H., and Keutsch, F. N.: Conversion of hydroperoxides to carbonyls in field and laboratory instrumentation: observational bias in diagnosing pristine versus anthropogenically-controlled atmospheric chemistry, Geophys. Res. Lett., 41, 8645-8651, doi:10.1002/2014GL061919, 2014.

Rohrer, F., Lu, K. D., Hofzumahaus, A., Bohn, B., Brauers, T., Chang, C. C., Fuchs, H., Haseler, R., Holland, F., Hu, M., Kita, K., Kondo, Y., Li, X., Lou, S. R., Oebel, A., Shao, M., Zeng, L. M., Zhu, T., Zhang, Y. H., and Wahner, A.: Maximum efficiency in the hydroxyl-radical-based self-cleansing of the troposphere, Nat. Geosci., 7, 559-563, doi:10.1038/ngeo2199, 2014.

Ryerson, T. B., Williams, E. J., and Fehsenfeld, F. C.: An efficient photolysis system for fast-response $\mathrm{NO}_{2}$ measurements, J. Geophys. Res.-Atmos., 105, 26447-26461, doi:10.1029/2000jd900389, 2000.

Sakulyanontvittaya, T., Duhl, T., Wiedinmyer, C., Helmig, D., Matsunaga, S., Potosnak, M., Milford, J., and Guenther, A.: Monoterpene and sesquiterpene emission estimates for the United States, Environ. Sci. Technol., 42, 1623-1629, doi:10.1021/es702274e, 2008.

Saunders, S. M., Jenkin, M. E., Derwent, R. G., and Pilling, M. J.: Protocol for the development of the Master Chemical Mechanism, MCM v3 (Part A): tropospheric degradation of non- aromatic volatile organic compounds, Atmos. Chem. Phys., 3, 161-180, doi:10.5194/acp-3-161-2003, 2003.

Schauer, J. J., Kleeman, M. J., Cass, G. R., and Simoneit, B. R. T.: Measurement of emissions from air pollution sources. 2. C-1 through C-30 organic compounds from medium duty diesel trucks, Environ. Sci. Technol., 33, 1578-1587, doi:10.1021/es980081n, 1999.

Stammes, P., Sneep, M., De Haan, J. F., Veefkind, J. P., Wang, P., and Levelt, P. F.: Effective cloud fractions from the Ozone Monitoring Instrument: Theoretical framework and validation, J. Geophys. Res.-Atmos., 113, D16S38, doi:10.1029/2007jd008820, 2008.

Stavrakou, T., Müller, J.-F., De Smedt, I., Van Roozendael, M., Kanakidou, M., Vrekoussis, M., Wittrock, F., Richter, A., and Burrows, J. P.: The continental source of glyoxal estimated by the synergistic use of spaceborne measurements and inverse modelling, Atmos. Chem. Phys., 9, 8431-8446, doi:10.5194/acp-98431-2009, 2009.

Tawfik, A. B., Stöckli, R., Goldstein, A., Pressley, S., and Steiner, A. L.: Quantifying the contribution of environmental factors to isoprene flux interannual variability, Atmos. Environ., 54, 216224, doi:10.1016/j.atmosenv.2012.02.018, 2012.

Volkamer, R., Baidar, S., Campos, T. L., Coburn, S., DiGangi, J. P., Dix, B., Eloranta, E. W., Koenig, T. K., Morley, B., Ortega, I., Pierce, B. R., Reeves, M., Sinreich, R., Wang, S., Zondlo, M. A., and Romashkin, P. A.: Aircraft measurements of BrO, $\mathrm{IO}$, glyoxal, $\mathrm{NO}_{2}, \mathrm{H} 2 \mathrm{O}, \mathrm{O}_{2}-\mathrm{O}_{2}$ and aerosol extinction profiles in the tropics: comparison with aircraft-/ship-based in situ and lidar measurements, Atmos. Meas. Tech., 8, 2121-2148, doi:10.5194/amt-8-2121-2015, 2015.

Vrekoussis, M., Wittrock, F., Richter, A., and Burrows, J. P.: GOME-2 observations of oxygenated VOCs: what can we learn from the ratio glyoxal to formaldehyde on a global scale?, Atmos. Chem. Phys., 10, 10145-10160, doi:10.5194/acp-1010145-2010, 2010.

Washenfelder, R. A., Wagner, N. L., Dube, W. P., and Brown, S. S.: Measurement of Atmospheric Ozone by Cavity Ringdown Spectroscopy, Environ. Sci. Technol., 45, 2938-2944, doi:10.1021/es103340u, 2011.

Wiedinmyer, C., Greenberg, J., Guenther, A., Hopkins, B., Baker, K., Geron, C., Palmer, P. I., Long, B. P., Turner, J. R., Petron, G., Harley, P., Pierce, T. E., Lamb, B., Westberg, H., Baugh, W., Koerber, M., and Janssen, M.: Ozarks Isoprene Experiment (OZIE): Measurements and modeling of the "isoprene volcano", J. Geophys. Res.-Atmos., 110, D18307, doi:10.1029/2005jd005800, 2005.

Wolfe, G. M. and Thornton, J. A.: The Chemistry of AtmosphereForest Exchange (CAFE) Model - Part 1: Model description and characterization, Atmos. Chem. Phys., 11, 77-101, doi:10.5194/acp-11-77-2011, 2011.

Zhou, S., Gonzalez, L., Leithead, A., Finewax, Z., Thalman, R., Vlasenko, A., Vagle, S., Miller, L.A., Li, S.-M., Bureekul, S., Furutani, H., Uematsu, M., Volkamer, R., and Abbatt, J.: Formation of gas-phase carbonyls from heterogeneous oxidation of polyunsaturated fatty acids at the air-water interface and of the sea surface microlayer, Atmos. Chem. Phys., 14, 1371-1384, doi:10.5194/acp-14-1371-2014, 2014. 